\title{
A brief history of market efficiency
}

\author{
Elroy Dimson and Massoud Mussavian*
}

London Business School, Sussex Place, Regents Park, London NW1 4SA, UK. E-mail: edimson@lbs.ac.uk and mmussavian@sbil.co.uk

\begin{abstract}
Every finance professional employs the concept of market efficiency. The theory, evidence and counterevidence focus on a couple of dozen highly influential articles published during the twentieth century. We summarise the origins of and interlinkages between these contributions to the history of finance.
\end{abstract}

Keywords: Market efficiency, stock market anomalies, market microstructure, history of finance, literature review

JEL classification: $B 00, G 14$.

\section{Introduction}

The concept of efficiency is central to finance. Primarily, the term efficiency is used to describe a market in which relevant information is impounded into the price of financial assets. This is the primary focus of the articles reviewed here. Sometimes, however, economists use this word to refer to operational efficiency, emphasising the way resources are employed to facilitate the operation of the market. Most of this review is concerned with the former definition, namely the informational efficiency of financial markets. At the end of this paper, we also consider the microstructure of financial markets.

If capital markets are sufficiently competitive, then simple microeconomics indicates that investors cannot expect to achieve superior profits from their investment strategies. But although this appears self-evident today, it was far from obvious for the majority of the century. Up to the end of the 1950s, there were few theoretical or empirical studies of securities markets; and until Cootner (1964) collated a selection of papers from a wide variety of sources, the literature was dispersed across journals in statistics, operations research, mathematics and economics.

The concept of market efficiency had been anticipated at the beginning of the century in the dissertation submitted by Bachelier (1900) ${ }^{1}$ to the Sorbonne for his $\mathrm{PhD}$ in mathematics. In his opening paragraph, Bachelier recognises that "past, present and even discounted future events are

We have benefitted from comments by Ray Ball, Dick Brealey, Michel Habib, Carolina Minio Paluello, Narayan Naik and colleagues at London Business School, and by the editor, John Doukas.

A selection of seminal articles in the areas of market efficiency and stock market anomalies are identified by being printed in bold typeface. These articles are to be published in Volume 1 of Elroy Dimson and Massoud Mussavian Foundations of Finance (Dartmouth Publishing Company, 1998). Further articles, identified by italicised bold typeface, are included in Volumes II and III. 
reflected in market price, but often show no apparent relation to price changes". This recognition of the informational efficiency of the market leads Bachelier to continue,

in his opening paragraphs, that "if the market, in effect, does not predict its fluctuations, it does assess them as being more or less likely, and this likelihood can be evaluated mathematically". This gives rise to a brilliant analysis that anticipates not only Albert Einstein's subsequent derivation of the Einstein-Wiener process of Brownian motion, but also many of the analytical results that were rediscovered by finance academics in the second half of the century. Sadly, Bachelier's contribution was overlooked until it was circulated to economists by Paul Samuelson in the late 1950s (see Bernstein, 1992) and subsequently published in English by Cootner (1964).

Although there could have been an emerging theory of speculative markets during the first half of the twentieth century, this was not to be. Instead, the early literature followed the path of accumulating a variety of empirical observations that did not sit easily alongside the paradigms of economics or the beliefs of practitioners. Bachelier had concluded that commodity prices fluctuate randomly, and later studies by Working (1934) and Cowles and Jones (1937) were to show that US stock prices and other economic series also share these characteristics. These studies were largely overlooked by researchers until the late 1950s.

There was, in addition, disturbing evidence about the difficulty of beating the equity market. Alfred Cowles III, founder of the Cowles Commission and benefactor of the Econometric Society, published in the launch issue of Econometrica a painstaking analysis of many thousands of stock selections made by investment professionals. Cowles (1933) found that there was no discernable evidence of any ability to outguess the market. Subsequently, Cowles (1944) provided corroborative results for a large number of forecasts over a much longer sample period. By the 1940s, there was therefore scattered evidence in favour of the weak and strong form efficiency of the market, though these terms were not yet in use.

\section{The Random Walk Model}

The problem of the optimal search procedure for finding a drunk left in a middle of a field was discussed early in the century by Karl Pearson (1905). If the drunk can be expected to stagger in a totally unpredictable and random fashion, he is likely to end up closer to where he had been left than to any other point.

In finance, this analogy has been applied to series whose successive returns are serially independent (a more precise definition is provided in Fama, 1965, reviewed below). In the early 1950s researchers were, for the first time, able to use electronic computers to study the behaviour of lengthy price series. The assumption of economists was that one could "analyse an economic time series by extracting from it a long-term movement, or trend, for separate study and then scrutinising the residual portion for short-term oscillatory movements and random fluctuations" (Kendall, 1953).

When Kendall examined 22 UK stock and commodity price series, however, the results surprised him. He concluded that "in series of prices which are observed at fairly close intervals the random changes from one term to the next are so large as to swamp any systematic effect which may be present. The data behave almost like wandering series." The near-zero serial correlation of price changes was an observation that appeared inconsistent with the views of economists. Nevertheless, these empirical observations came to be labelled the "random walk model" or even the "random walk theory". 
If prices wander randomly, then this poses a major challenge to market analysts who try to predict the future path of security prices. Drawing on Kendall's work and earlier research by Working (1934), Roberts (1959) demonstrated that a time series generated from a sequence of random numbers was indistinguishable from a record of US stock prices - the raw material used by market technicians to predict future price levels. "Indeed," he wrote, "the main reason for this paper is to call to the attention of financial analysts empirical results that seem to have been ignored in the past, for whatever reason, and to point out some methodological implications of these results for the study of securities."

Whereas Roberts was throwing the gauntlet to practitioners, Osborne (1959) analysed US stock price data out of pure academic interest, presenting his results to other physicists at the US Naval Research Laboratory. Osborne shows that common stock prices have properties analogous to the movement of molecules. He applies the methods of statistical mechanics to the stock market, with a detailed analysis of stock price fluctuations from the point of view of a physicist.

Despite the emerging evidence on the randomness of stock price changes, there were occasional instances of anomalous price behaviour, where certain series appeared to follow predictable paths. This includes a subset of the stock and commodity price series examined by Working (1934), Cowles and Jones (1937) and Kendall (1953).

In 1960, however, there was a realisation that autocorrelation could be induced into returns series as a result of using time-averaged security prices. Working (1960) and Alexander (1961) independently discovered this. Once returns series are based on end-of-period prices, returns appear to fluctuate randomly. The problem of time-averaging identified by Working is the first research on thin trading (see Dimson, 1979) and a precursor to studies of market microstructure (see section 5 below).

The mid-1960s was a turning point in research on the random character of stock prices. In 1964, Cootner published his collection of papers on that topic, while Fama's (1965) doctoral dissertation was reproduced, in its entirety, in the Journal of Business. Fama reviews the existing literature on stock price behaviour, examines the distribution and serial dependence of stock market returns, and concludes that "it seems safe to say that this paper has presented strong and voluminous evidence in favour of the random walk hypothesis."

\section{Market Efficiency}

\subsection{The concept of market efficiency}

With a better understanding of price formation in competitive markets, the random walk model came to be seen as a set of observations that can be consistent with the efficient markets hypothesis.

The switch of emphasis began with observations such as that of Samuelson (1965), whose Proof That Properly Anticipated Prices Fluctuate Randomly began with the observation that "in competitive markets there is a buyer for every seller. If one could be sure that a price would rise, it would have already risen." Samuelson asserted that "arguments like this are used to deduce that competitive prices must display price changes... that perform a random walk with no predictable 
bias."

Samuelson explains that "we would expect people in the market place, in pursuit of avid and intelligent self-interest, to take account of those elements of future events that in a probability sense may be discerned to be casting their shadows before them." By presenting his proof in a general form, Samuelson added rigour to our notion of a well-functioning market. It is not clear to us whether these results ought to be seen as obvious or surprising, nor was it clear to Samuelson who wrote that "the theorem is so general that I must confess to having oscillated over the years in my own mind between regarding it as trivially obvious (and almost trivially vacuous) and regarding it as remarkably sweeping. Such perhaps is characteristic of basic results."

Building on Samuelson's microeconomic approach, together with a taxonomy suggested by Harry Roberts (1967), Fama (1970) assembled a comprehensive review of the theory and evidence of market efficiency. Though his paper proceeds from theory to empirical work, he notes that most of the empirical work preceded development of the theory.

The theory involves defining an efficient market as one in which trading on available information fails to provide an abnormal profit. A market can be deemed to be efficient, therefore, only if we posit a model for returns. From this point on, tests of market efficiency become joint tests of market behaviour and models of asset pricing. We discuss this issue later.

The weak form of the efficient market hypothesis claims that prices fully reflect the information implicit in the sequence of past prices. The semi-strong form of the hypothesis asserts that prices reflect all relevant information that is publicly available, while the strong form of market efficiency asserts information that is known to any participant is reflected in market prices. The literature begins, therefore, with studies of weak form market efficiency.

Fama (1970) summarises the early random walk literature, his own contributions and other studies of the information contained in the historical sequence of prices, and concludes that "the results are strongly in support" of the weak form of market efficiency. He then reviews a number of semistrong and strong form tests, highlighting those that we cover in the next two sections, and concludes that "in short, the evidence in support of the efficient markets model is extensive, and (somewhat uniquely in economics) contradictory evidence is sparse." He concedes, however, that "much remains to be done", and indeed, Fama (1991) subsequently returned to the fray with a reinterpretation of the efficient markets hypothesis in the light of subsequent research.

\subsection{Event studies}

Studies of the semi-strong form of the efficient markets hypothesis can be categorised as tests of the speed of adjustment of prices to new information. The principal research tool in this area is the event study. An event study averages the cumulative performance of stocks over time, from a specified number of time periods before an event to a specified number of periods after. Performance for each stock is measured after adjusting for market-wide movements in security prices. The first event study was undertaken by Fama, Fisher, Jensen and Roll (1969), though the first to be published was by Ball and Brown (1968).

Using the market model or capital asset pricing model as the benchmark, these event studies 
provide evidence on the reaction of share prices to stock splits and earnings announcements respectively. In both cases, the market appears to anticipate the information, and most of the price adjustment is complete before the event is revealed to the market. When news is released, the remaining price adjustment takes place rapidly and accurately. The Fama, Fisher, Jensen and Roll study, in particular, demonstrates that prices reflect not only direct estimates of prospective performance by the sample companies, but also information that requires more subtle interpretation.

In Scholes' (1972) study of the price effects of secondary offerings, he examines stock price movements when the seller may be in possession of non-public information. On average, share prices fall by an amount that reflects the value of this information. The impact of a secondary distribution on the stock price is largely unaffected by the size of the transaction, which confirms the depth of the market and the substitutability of one security for another. Note, however, that there is some indication of post-event price drift, which may constitute a violation of market efficiency.

\subsection{Strong form efficiency}

Since the first event studies, numerous papers have demonstrated that early identification of new information can provide substantial profits. Insiders who trade on the basis of privileged information can therefore make excess returns, violating the strong form of the efficient markets hypothesis. Even the earliest studies by Cowles (1933, 1944), however, make it clear that investment professionals do not beat the market.

While there was evidence on the performance of security analysts, until the 1960s there was a gap in knowledge about the returns achieved by professional portfolio managers. With the development of the capital asset pricing model by Treynor (1961) and Sharpe (1964) it became clear that the CAPM can provide a benchmark for performance analysis. The first such study was Treynor's (1965) article in Harvard Business Review on the performance of mutual funds, closely followed by Sharpe's (1966) rival article.

The most frequently cited article on fund managers' performance was to be the detailed analysis of 115 mutual funds over the period 1955-64 undertaken by Jensen (1968). On a risk-adjusted basis, he finds that any advantage that the portfolio managers might have is consumed by fees and expenses. Even if investment management fees and loads are added back to performance measures, and returns are measured gross of management expenses (ie, assuming research and other expenses were obtained free), Jensen concludes that "on average the funds apparently were not quite successful enough in their trading activities to recoup even their brokerage expenses." Fama (1991) summarises a number of subsequent studies of mutual fund and institutional portfolio managers's performance. Though some mutual funds have achieved minor abnormal gross returns before expenses, pension funds have underperformed passive benchmarks on a risk-adjusted basis.

It is important to note that the efficient markets hypothesis does not rule out small abnormal returns, before fees and expenses. Analysts could therefore still have an incentive to acquire and act on valuable information, though investors would expect to receive no more than an average net return. Grossman and Stiglitz (1980) formalise this idea, showing that a sensible model of equilibrium must leave some incentive for security analysis. 
To make sense, the concept of market efficiency has to admit the possibility of minor market inefficiencies. The evidence accumulated during the 1960s and 1970s appeared to be broadly consistent with this view. While it was clear that markets cannot be completely efficient in the strong form, there was striking support for the weak and semi-strong forms, and even for versions of strong form efficiency that focus on the performance on professional investment managers.

\section{Stock Market Anomalies}

\subsection{Value, size and other regularities}

There were, of course, occasional studies with contrary results, but until the 1980s these did not appear to be important. Basu (1977) documented the use of price/earnings ratios to forecast stock returns. In a study of 1400 firms over the period 1956-71, he observes low p/e securities outperforming their high p/e counterparts by more than seven percent per year. Though his results could be interpreted as a challenge to the CAPM benchmark that he employs, Basu regards his results as indicative of a market inefficiency: "Securities trading at different multiples of earnings, on average, seem to have been inappropriately priced vis-a-vis one another, and opportunities for earning "abnormal" returns were afforded to investors."

Ball and Brown (1968) had already noted evidence of post-earnings announcement "drift" in the direction indicated by an earnings surprise. Ten years later, the first published paper to draw together literature on earnings-related anomalies was the survey by Ball (1978). In an appendix, he summarised twenty studies of earnings and dividends, and concluded that the collective evidence of anomalous behaviour was strong.

Basu's study of low p/e stocks was followed by publication of Banz's (1981) work on the long-run rate of return from investing in smaller companies. Banz analyses monthly returns over the period 1931-75 on shares listed on the New York Stock Exchange. Over this interval, the fifty smallest stocks outperformed the fifty largest by an average of one percentage point per month, on a riskadjusted basis. The small firm effect documented by Banz gave rise to a plethora of papers examining this phenomenon (see Schwert, 1983) and has been corroborated in many different countries (see Dimson and Marsh, 1989).

In addition to earnings- and size-related regularities in returns, there are a number of other puzzling observations that present a challenge to the efficient markets hypothesis. A phenomenon that has not yet been explained satisfactorily is the negative long-run performance of new issues, documented by Ritter (1991) and Loughran and Ritter (1995). Using a sample of 1526 initial public offerings over the period 1975-84, Ritter finds that an initial investment in these shares at the end of the first day of trading would have generated substantial underperformance over the following three years, relative to a wide variety of benchmarks including a detailed matching procedure that controls for the market capitalisation and industry of each security.

A central difficulty in interpreting studies such as these is the joint hypothesis problem. The magnitude of over- or under-performance depends critically on the choice of benchmark (see Dimson and Marsh, 1986), and this makes it difficult to interpret the results. On the one hand, 
anomalous behaviour may be an indication of market inefficiencies. On the other hand, even if there is no bias or misestimation in computed abnormal returns, the regularity in returns may be indicative of shortcomings in the underlying asset pricing model.

Fama and French (1992) show that two variables, closely related to Basu's earnings and Banz's size variables, capture much of the cross-sectional variation in stock returns over the period 19631990. These results have been confirmed for a wide variety of non-US markets as well; see, for example, Arshanapalli, Coggin and Doukas (1998). The main finding of Fama and French is that market capitalisation and book-to-market equity subsumes the impact not only of these two variables but also of price/earnings ratios and leverage. The Fama and French result may be consistent with asset pricing theory, in which case the model can be regarded as an empirical model in the spirit of arbitrage pricing theory. Alternatively, the influence of book-to-market equity, the most powerful explanatory variable, may result from market overreaction, though the authors report that simple tests do not confirm that size and book-to-market effects are due to the type of market overreaction posited by, amongst others, DeBondt and Thaler (1985) (see section 4.3 below).

In addition to the regularities discussed in this section, there is also a literature on stock market seasonalities, including month-of-the-year, week-of-the-month, day-of-the-week, and hour-of-theday effects (see Rozeff and Kinney (1976) and Keim (1983), Ariel (1987), French (1980), and Harris (1986) respectively). As discussed in Dimson (1988), some of these patterns, notably the January seasonal of small stock returns, may be consistent with either market inefficiencies or seasonalities in asset pricing. Other patterns, notably those observed over very short periods, may be explained better by market microstructure, a topic we defer to section 5 .

\subsection{Tests of fundamental valuation}

Event studies, and many strong form tests, indicate that security prices respond efficiently to new information. It remains possible that assets may be persistently over- or under-valued over long periods of time. It is more difficult to test whether prices conform to fundamental values, than it is to test whether prices respond appropriately to information. Nonetheless, despite the difficulty of testing whether the level of security prices is correct, the literature has also evolved in this direction. The two major challenges to the rational efficiency of the market are, first, the variance bounds literature, which we review here; and second, the noise trader literature discussed later.

Shiller (1981) examines the variation in stock market prices, and finds that price fluctuations are too large to be justified by the subsequent variation in dividend payments. Shiller finds that "measures of stock price volatility over the past century appear to be far too high - five to thirteen times too high - to be attributed to new information about future real dividends.... The failure of the efficient markets model is thus so dramatic that it would seem impossible to attribute the failure to such things as data errors, price index problems, or changes in tax laws." This extension to the equity market of Shiller's (1979) earlier work on the bond market suffers from a similar limitation to the anomalies outlined earlier. That is, his procedure is a joint test of market efficiency and the validity of his model of the dividend process. This literature has attracted considerable controversy (eg, Kleidon, 1986) as well as generating "second generation" variance bounds tests such as those reviewed in Gilles and LeRoy (1991). 
One of the difficulties of interpreting the variance bounds literature is the central assumption that excess price volatility implies market inefficiency. This assertion would seem to be bound up with the question of the survivorship of markets. The fact that the US market survived 1929, or the UK survived 1974, may well imply excessive price volatility, on an ex post basis, over the sample period. But as Brown, Goetzmann and Ross (1995) and Goetzmann and Jorion (1997) point out, most stock markets fail to survive. For the latter, dividend volatility may have been infinite, and the (pre-failure) variance of stock prices was therefore too low to be justified by subsequent dividend behaviour.

Similar considerations may apply to Mehra and Prescott's (1985) equity premium puzzle. Mehra and Prescott consider a simple model based on consumers' preferences and the economic process generating consumption. Calibrating the key statistical characteristics of their assumptions, they cannot reproduce the long-run equity premia generated by the market, given interest rates. They show that, in their version of the model, with average risk-free interest rates in the range zero to four percent, the mean premium would not exceed 0.35 percent. This compares with a US equity risk premium over the period 1889-1978 of seven percent per year.

Apart from focusing on survivor-type arguments, in which Mehra and Prescott's model is modified to include a small probability of catastrophic events (Rietz, 1988), there have also been other approaches to modifying the underlying model, generalising the assumed preferences of consumers, and revising the empirical analysis. The equity risk premium puzzle continues to attract research interest.

\subsection{Tests of overreaction and underreaction}

Finally, we turn to some other tests which focus on return predictability. These tests fall into two groups. First, and contrary to the early random walk literature, a number of studies have found evidence of positive autocorrelation in security returns over weekly and monthly time horizons; and second there is an indication of negative serial correlation in longer horizon returns over periods of several years. Despite several researchers' claims of large arbitrage opportunities from exploiting the autocorrelation in short-term returns, it is doubtful whether any abnormal returns remain after accounting for the trading spreads, commissions and other costs involved in pursuing this kind of short-term momentum strategy.

Longer term mispricing, however, could constitute a more serious violation of market efficiency. The research on time series dependencies in returns which has had the largest impact, at least with practitioners, is the study by DeBondt and Thaler (1985). DeBondt and Thaler look at returns over longer horizons, finding that stocks which have underperformed the most over a three- to fiveyear period average the highest market-adjusted returns over the subsequent period, and vice versa. They explain this pattern of return reversal as an overreaction in the market in which stock prices diverge from fundamental value. Jegadeesh and Titman (1993) have observed a similar phenomenon, arguing that such price behaviour is consistent with positive feedback trading.

Poterba and Summers (1988), together with Fama and French (1988a,b), discuss the linkage between short-horizon positive serial correlation in stock returns, accompanied by negative correlation over longer intervals. Poterba and Summers suggest that their findings are indicative of a market inefficiency: "Noise trading, trading by investors whose demand for shares is determined 
by factors other than their expected return, provides a plausible explanation for the transitory components in stock prices."

Whether these longer horizon patterns of mean reversion really exist is a matter of controversy, since subperiod results suggest that the patterns observed by DeBondt and Thaler (1985) and Poterba and Summers (1988) are not all that robust over time. Time-varying expected returns could also explain these patterns, without requiring us to assume that prices deviate from fundamental value over extended intervals. Nevertheless, there is a growing literature that seeks to explain observations such as these in terms of the sentiment of non-rational noise traders, an idea introduced in the next section.

\section{Market Microstructure}

The classic paper on market microstructure is Jack Treynor's short article on The Only Game in Town (written under the pseudonym of Bagehot, 1971). In this article, Treynor explains why investors as a whole lose from trading, and why informed investors win. The key is to understand the role of the dealer or market-maker, who loses when trading with informed investors, but aims to more than recoup these losses through trading with uninformed investors.

Grossman and Stiglitz (1980) observed that in a world with costly information, it is impossible for markets to be informationally efficient. They resolve this paradox by drawing on Treynor's idea of assuming that the market also entertains transactions from uninformed noise traders. This focus on the way that markets function has grown into an extensive literature on the microstructure of financial markets. The Bagehot (1971) article provided an early insight into the way information is incorporated into security prices through the activities of investors, and how market structure can have an impact on the efficiency of the stock market.

The intuitive story told by Bagehot is formalised in the price formation model presented by Kyle (1985). Kyle develops a model in which multiple orders of variable size are processed at a single price. His model has three types of traders: a single informed trader, several competing market makers, and uninformed noise traders who transact randomly. Noise traders camouflage the activities of the informed trader, whose transactions are organised in such a way that his private information is reflected gradually in market prices. The market makers compete and therefore break even while informed transactors achieve a profit at the expense of noise traders.

Glosten and Milgrom (1985) showed that the very possibility of trading on information can be sufficient to induce a positive bid-ask spread. Building on earlier work by Copeland and Galai (1983), Glosten and Milgrom identify the element of the spread that is attributable to adverse selection. Taken together with Demsetz's (1968) order processing costs, and Ho and Stoll's (1981) measure of inventory control costs, this has provided a framework that this is now used widely for analysing the bid-ask spread confronted by investors.

The concept of noise traders has had an impact on financial modelling that goes beyond the field of market microstructure. We alluded to their role in the context of the DeBondt and Thaler (1985) and Poterba and Summers (1988) studies of predictability in stock price behaviour, and they are discussed further in Black's (1986) address. The basic ideas, developed in Bagehot (1971), are in fact employed in many applications. 


\section{Conclusion}

The efficient markets hypothesis is simple in principle, but remains elusive. Evolving from an initially puzzling set of observations about the random character of security prices, it became the dominant paradigm in finance during the 1970s. During its heyday, the efficient markets hypothesis came to be supported by a growing body of empirical research demonstrating the difficulty of beating the market, whether by analysing publicly available information or by employing professional investment advisors.

Testing for market efficiency, however, is difficult. We have documented a number of studies that indicate anomalous behaviour which appears, at first sight, to be inconsistent with market efficiency. Ball (1978) points out that such evidence may equally well be interpreted as indicative of shortcomings in our models of expected returns. Indeed, Fama (1997) takes issue with the view that apparent anomalies require new behaviourally based theories of the stock market. Rather, they are indicative of a need to continue the search for better models of asset pricing.

The last two decades have witnessed an onslaught against the efficient markets hypothesis. Yet as Roll (1994) observes, it is remarkably hard to profit from even the most extreme violations of market efficiency. Stock market anomalies are only too often chance events that do not persist into the future. The importance of the efficient markets hypothesis is demonstrated by the fact that apparently profitable investment opportunities are still referred to as "anomalies". The efficient markets model continues to provide a framework that is widely used by financial economists.

\section{REFERENCES}

Alexander, Sydney (1961). "Price Movements in Speculative Markets: Trends or Random Walks", Industrial Management Review, 2, pp 7-26.

Ariel, Robert (1987), "A Monthly Effect in Stock Returns", Journal of Financial Economics, 18, pp 161-174.

Arshanapalli, Bala, Daniel Coggin and John Doukas (1998). "Multifactor Asset Pricing Analysis of International Investment Strategies". Abstracted in Journal of Finance, July.

Bachelier, Louis (1900) trans. James Boness. "Theory of Speculation", in Cootner (1964) pp. 17-78.

Bagehot, Webster pseud. for Jack Treynor (1971). "The Only Game in Town", Financial Analysts Journal, 27 (Mar/Apr), pp. 12-17.

Ball, Ray (1978). "Anomalies in Relationships Between Securities' Yields and Yield-Surrogates", Journal of Financial Economics, 6, pp. 103-26.

In bold typeface we identify articles to be published in Volume I of Elroy Dimson and Massoud Mussavian Foundations of Finance (Dartmouth Publishing Company) 1998. Further articles, identified by italicised bold typeface, are included in Volumes II and III. 
Ball, Ray and Philip Brown (1968). "An Empirical Evaluation of Accounting Income Numbers", Journal of Accounting Research, 6, pp. 159-178.

Black, Fischer (1986). "Noise", Journal of Finance, 41, pp. 529-543.

Banz, Rolf (1981). "The Relationship Between Return and Market Value of Common Stocks", Journal of Financial Economics, 9, pp. 3-18.

Basu, Sanjoy (1977). "The Investment Performance of Common Stocks in Relation to their Price to Earnings Ratio: A Test of the Efficient Markets Hypothesis", Journal of Finance, 32, pp. 663-682.

Bernstein, Peter (1992). Capital Ideas: The Improbable Origins of Modern Wall Street, Free Press.

Brown, Stephen, William Goetzmann and Stephen Ross (1995). "Survival", Journal of Finance, 50, pp. 853873.

Cootner, Paul (ed.) (1964). The Random Character of Stock Market Prices, MIT Press.

Copeland, Thomas and Dan Galai (1983). "Information Effects on the Bid-Ask Spread", Journal of Finance, 38, pp. 1457-1469.

Cowles, Alfred 3rd (1933). "Can Stock Market Forecasters Forecast?", Econometrica, 1, pp. 309-324.

Cowles, Alfred 3rd and H Jones (1937). "Some A Posteriori Probabilities in Stock Market Action", Econometrica, 5, pp. 280-294.

Cowles, Alfred 3rd (1944). "Stock Market Forecasting", Econometrica, 12, pp. 206-214.

DeBondt, Werner and Richard Thaler (1985). "Does the Stock Market Overreact?", Journal of Finance, 40, pp. 793-805.

Demsetz, Harold (1968). "The Cost of Trading", Quarterly Journal of Economics, 82, pp. 33-53.

Dimson, Elroy (1979). "Risk Measurement When Shares are Subject to Infrequent Trading", Journal of Financial Economics, 7, pp. 197-226.

Dimson, Elroy (1988). Stock Market Anomalies, Cambridge University Press.

Dimson, Elroy and Paul Marsh (1986). "Event Study Methodologies and the Size Effect: The Case of UK Press Recommendations", Journal of Financial Economics, 17, pp 113-142.

Dimson, Elroy and Paul Marsh (1989). "The Smaller Companies Puzzle", Investment Analyst, 91, pp. 16-24.

Dimson, Elroy and Massoud Mussavian (eds) (1998a). Foundations of Finance Volume I: Market Efficiency, Dartmouth Publishing Company.

Dimson, Elroy and Massoud Mussavian (eds) (1998b). Foundations of Finance Volume II: Asset Pricing, Dartmouth Publishing Company.

Dimson, Elroy and Massoud Mussavian (eds) (1998c). Foundations of Finance Volume III: Corporate Finance, Dartmouth Publishing Company.

Fama, Eugene (1965). "The Behavior of Stock Market Prices", Journal of Business, 38, pp. 34-105. 
Fama, Eugene (1970). "Efficient Capital Markets: A Review of Theory and Empirical Work", Journal of Finance, 25, pp. 383-417.

Fama, Eugene (1991). "Efficient Capital Markets II", Journal of Finance, 46, pp. 1575-617.

Fama, Eugene (1997). "Market Efficiency, Long-Term Returns and Behavioural Finance", CRSP Working Paper 448, University of Chicago.

Fama, Eugene, Lawrence Fisher, Michael Jensen and Richard Roll (1969). "The Adjustment of Stock Prices to New Information", International Economic Review, 10, pp. 1-21.

Fama, Eugene and Kenneth French (1988a). "Dividend Yields and Expected Stock Returns", Journal of Financial Economics, 22, pp. 3-25.

Fama, Eugene and Kenneth French (1988b). "Permanent and Temporary Components of Stock Prices", Journal of Political Economy, 96, pp. 246-273.

Fama, Eugene and Kenneth French (1992). "The Cross-Section of Expected Returns", Journal of Finance, 47, pp. 427-465.

French, Kenneth (1980). "Stock Returns and the Weekend Effect", Journal of Financial Economics, 8, pp. 5569.

Gilles, Christian and Stephen LeRoy (1991). "Econometric Aspects of the Variance-Bounds Tests: A Survey", Review of Financial Studies, 4, pp. 753-791.

Glosten, Lawrence and Paul Milgrom (1985). "Bid, Ask, and Transactions Prices in a Specialist Market With Heterogeneously Informed Traders", Journal of Financial Economics, 14, pp. 71-100.

Goetzmann, William and Philippe Jorion (1997). "A Century of Global Stock Markets", working paper 5091, National Bureau of Economic Research.

Grossman, Sanford and Joseph Stiglitz (1980). "On the Impossibility of Informationally Efficient Markets", American Economic Review, 70, pp. 393-408.

Harris, Lawrence (1986). "A Transaction Data Study of Weekly and Intradaily Patterns in Stock Returns", Journal of Financial Economics, 16, pp. 99-117.

Ho, Thomas and Hans Stoll (1981). "Optimal Dealer Pricing Under Transactions and Return Uncertainty", Journal of Financial Economics 9, pp. 47-73.

Jegadeesh, Narasimhan and Sheridan Titman (1993). "Returns to Buying Winners and Selling Losers: Implications for Stock Market Efficiency", Journal of Finance, 48, pp. 65-91.

Jensen, Michael (1968). "The Performance of Mutual Funds in the Period 1945-1964", Journal of Finance, 23, pp. 389-416.

Keim, Donald (1983). "Size-Related Anomalies and Stock Return Seasonality: Further Empirical Evidence", Journal of Financial Economics, 12, pp 13-32.

Kendall, Maurice (1953). "The Analysis of Economic Time Series", Journal of the Royal Statistical Society, Series A, 96, pp. 11-25.

Kleidon, Allan (1986). "Variance Bounds Tests and Stock Price Valuation Models", Journal of Political 
Economy, 94, pp. 953-1001.

Kyle, Albert (1985). "Continuous Auctions and Insider Trading", Econometrica, 53, pp. 1315-1335.

Loughran, Tim and Jay Ritter (1995). "The New Issues Puzzle", Journal of Finance, 50, pp 23-51.

Mehra, Rajnish and Edward Prescott (1985). "The Equity Risk Premium: A Puzzle", Journal of Monetary Economics, 15, pp. 145-161.

Osborne, M F M (1959). "Brownian Motion in the Stock Market", Operations Research, 7, pp. 145-173.

Pearson, Karl (1905). "The Problem of the Random Walk", Nature, 72, p. 342.

Poterba, James and Lawrence Summers (1988). "Mean Reversion in Stock Prices: Evidence and Implications", Journal of Financial Economics, 22, pp. 27-59.

Rietz, Thomas (1988). "The Equity Risk Premium: A Solution", Journal of Monetary Economics, 22, pp. 117136.

Ritter, Jay (1991). "The Long-Run Performance of Initial Public Offerings", Journal of Finance, 46, pp. 3-28.

Roberts, Harry (1959). "Stock Market 'Patterns' and Financial Analysis: Methodological Suggestions", Journal of Finance, 44, pp. 1-10.

Roberts, Harry (1967). "Statistical Versus Clinical Prediction of the Stock Market". Unpublished manuscript, CRSP, University of Chicago, May.

Roll, Richard (1994). "What Every CEO Should Know About Scientific Progress in Economics: What is Known and What Remains to be Resolved", Financial Management, 23, pp. 69-75.

Rozeff, Michael and William Kinney (1976). "Capital Market Seasonality: The Case of Stock Returns", Journal of Financial Economics, 3, pp 370-402.

Samuelson, Paul (1965). "Proof That Properly Anticipated Prices Fluctuate Randomly", Industrial Management Review, 6, pp. 41-49.

Scholes, Myron (1972). "The Market for Securities: Substitution Versus Price Pressure and the Effects of Information on Share Prices", Journal of Business, 45, pp. 179-211.

Schwert, William (1983). "Size and Stock Returns, and Other Empirical Regularities", Journal of Financial Economics, 12, pp. 3-12.

Sharpe, William (1964). "Capital Asset Prices: A Theory of Market Equilibrium Under Conditions of Risk", Journal of Finance, 19, pp 425-442.

Sharpe, William (1966). "Mutual Fund Performance", Journal of Business, 39, pp 119-138

Shiller, Robert (1979). "The Volatility of Long-term Interest Rates and Expectations Models of the Term Structure", Journal of Political Economy, 87, pp. 1190-1219

Shiller, Robert (1981). "Do Stock Prices Move Too Much to be Justified by Subsequent Changes in Dividends?", American Economic Review, 71, pp. 421-436.

Treynor, Jack (1961). "Toward a Theory of Market Value of Risky Assets". Mimeo. 
Treynor, Jack (1965). "How to Rate Management of Investment Funds", Harvard Business Review, 43 (JanFeb), pp. 63-75.

Working, Holbrook (1934). "A Random Difference Series for Use in the Analysis of Time Series". Journal of the American Statistical Association, 29, pp. 11-24.

Working, Holbrook (1960). "Note on the Correlation of First Differences of Averages in a Random Chain". Econometrica, 28, pp. 916-918. 